\title{
Exit duration and unemployment determinants for Korean graduates
}

\author{
Jung-Yon Lim and Young-Min Lee $2^{2^{*}}$ (1)
}

\begin{abstract}
Purpose: This study aims to resolve Korea's youth unemployment problem by analyzing the exit duration and unemployment determinants for college graduates in Korea. More specifically, it identifies the factors that improve young people's employability by examining the impact of individual and college characteristics, employment preparation behavior, self-esteem, and job-seeking activities during college on reducing unemployment.

Design/methodology/approach: Data from the eighth to 11th Korean Education and Employment Panel surveys are compiled and analyzed. A survival analysis and Cox proportional hazards model are used. Survival analysis is a useful statistical method for data analysis to describe, explain, or predict the occurrence and timing of a particular event.

Findings: College graduates differ in their employment preparation behavior based on their individual and college characteristics. Women focus more on achieving a good grade point average. Men are more active in seeking jobs, with the type of college and major subjects affecting their participation in on-the-job training. Second, the longer a college graduate's unemployment exit duration is, the less likely it becomes that he or she will escape from unemployment. Third, self-esteem is an important factor in increasing the likelihood of escaping from unemployment. Fourth, while job-seeking activities have a positive effect on escaping unemployment, excessive employment preparation behavior has a negative effect.
\end{abstract}

Originality/value: The paper deals with a serious problematic situation of Korea's youth unemployment. Significant results were identified and several research implications were proposed to make potential contributions for future research on youth unemployment.

Keywords: Youth unemployment, Unemployment exit duration, Survival analysis, Korean Education and Employment Panel

JEL classification: J13, E24, 128, O15

\section{Introduction}

Youth unemployment is an emerging social issue worldwide. Low growth and economic downturns are contributing to an increasing unemployment rate globally. According to the International Labor Organization, the youth unemployment rate rose sharply from 2007 to 2010, reaching 13\% between 2012 and 2017 (ILO 2017). The problem has progressed such that the term

\footnotetext{
*Correspondence: ymlee@sookmyung.ac.kr

${ }^{2}$ Graduate School of Human Resource Development, Sookmyung Women's University, \#1013, Sunheon-Gwan, Chungpa-Dong, Yongsan-Gu, Seoul, South Korea

Full list of author information is available at the end of the article
}

generation jobless has been coined to refer to unemployed young people (Vogel 2015). The youth unemployment problem is thus a global phenomenon that erodes economic growth, and must be addressed to achieve social integration and resolve the generational divide.

According to Statistics Korea (2018), Korea's youth unemployment rate is $10 \%$, the highest since records began in 1999. Although the government has implemented policies and designated funds to resolve youth unemployment, these initiatives have produced no visible outcome. This is not a temporary issue caused by a cyclical economic downturn, but rather a complex issue with various structural problems such as prolonged low economic growth; a mismatch between the supply of and 
demand for college graduates in the labor market, exacerbated by the increase in Korea's overall education level; college graduates' selective job-seeking activities and their reluctance to lower expectations; and mandatory military service for young Korean men.

Delaying graduation to search for a job while remaining a student has become a typical practice for many young people in Korea. As a result, it now takes 5 or 6 years to graduate. Furthermore, young people are delaying graduation to build up their qualifications, hoping to find a better job when they do graduate. However, critics have argued that this practice does not necessarily guarantee them a better job. Indeed, taking a semester off or postponing graduation can further delay their entry into the labor market (Schmid 2013). As a result, graduates take 11 months on average to find their first job (Statistics Korea 2015) and employment quality is declining every year (ILO 2013).

Delaying graduation stops young people contributing as members of society and living independently from their parents. This, in turn, delays marriage, resulting in young people deciding not to have children, creating a low birth rate problem. These issues will cost the country in the long term, as the population begins to age and reduce in size. Indeed, these social problems have become sufficiently severe that young people are now considered to be the generation that has given up seven things, namely romantic relationships, marriage, children, social relationships, a house, dreams, and hope.

Since youth unemployment has a significant ripple effect across a country's economy and society, many studies have examined this problem. Most either focus on young people's private education and employment preparation behavior or analyze factors that affect their employment (Finnie 2004; Van der Klaauw et al. 2004; Wu 2011). Other studies examine labor market outcomes such as wages and employment type (Lee et al. 2005), while some identify the amount of time or other factors needed to enter the labour market successfully (SalasVelasco 2007). However, their findings vary depending on the data and analysis techniques used, which makes it difficult to develop effective policy. More importantly, most of these studies focus on young people who graduated before the mid-2000s, which means they are somewhat outdated since youth unemployment became particularly entrenched after 2010.

Based on the above-described gaps in the literature, this study examines the employment preparation behavior and unemployment exit duration of those who graduated college in 2012 to identify the factors that facilitated their employment. By doing so, it explores various employment support measures that aim to reduce the time it takes college graduates to search for and find a job. Specifically, this study attempts to answer the following research questions: How does unemployment exit duration vary with college graduates' characteristics? Which factors affect college graduates' escape from unemployment?

\section{Literature review}

\subsection{Status and characteristics of the Korean youth labor market}

One of the most important topics in relation to Korea's job policies is the issue of jobs for young people. The youth employment rate in Korea is on the rise and was at $42.5 \%$ in 2017 . This still falls substantially short of the total employment rate of $60.7 \%$ (Kim 2018). Considering the fact that the perceived unemployment rate is more than twice the official unemployment rate, the actual condition of youth employment could be more serious than indicated by statistics (Yoon et al. 2017). The quality of youth jobs in Korea, a significant portion of which are temporary, non-regular, and short-term, clearly reveals the seriousness of deteriorating conditions in the youth labor market (Bae 2017).

Notable characteristics of the Korean youth labor market include an increasing number of highly educated young people who are not currently engaged in education, employment, or training (NEET), along with academic inflation due to a high rate of entry into higher education, a widening dual structure of the labor market, and job mismatch.

First, an increased youth unemployment rate leads to more young people in NEET, and one of the Korean NEET's characteristics is that the percentage of college graduates is much higher than that of other countries. This contrasts with the fact that OECD member states have a higher percentage of high school graduate NEETs. Korean college graduate NEETs account for $24.4 \%$ of the total, which is the third highest among OECD member countries (OECD 2017). This comes from the job-seeking behavior of attempting to find a quality job, and prolongs highly educated young people's employment preparation period. This long employment preparation behavior leads to a vicious cycle, where young people give up finding a job altogether and become NEETs, due to the frustration they experience after failing to get a good job. This is strongly related to Korea's second characteristic: a high rate of entry into higher education. Compared to other countries, Korea has the lowest rate of entry into vocational high school, and the highest rate of higher education completion (70\% as of 2016), among OECD member states. Hence, the issue in Korea's youth labor market focuses on college graduates (Park and Lee 2014). Previous studies report that on an average, college graduates' performance in the labor market is higher than that of 
high school graduates, and graduates from top colleges located in the Seoul metropolitan area outperform those from colleges outside this area and other low-ranked colleges (Lee et al. 2016). Furthermore, while the performance of college graduates in the labor market differs slightly across majors, there is no significant difference except for some majors such as medicine or education.

Lastly, while many complex problems are at play in Korea's youth employment sector, there is a problem of mismatch between available jobs and jobseekers, as the connection between growth rate and employment has weakened due to prolonged low economic growth. Due to labor market dualization, the gap between large companies and regular jobs, and between small companies and non-regular jobs has widened, and young people's efforts to get into the primary labor market has led to a competitive employment preparation behavior (Hong 2018). As the education level has improved due to a high rate of college entry, and lost its competitiveness in the labor market, young people are looking to other skills to distinguish themselves through additional qualifications, including GPA, internship, and career counselling, which, in turn, delays young people's entry into the labor market.

\subsection{Factors affecting youth employment}

The factors that contribute to young people's success in finding employment can be broadly divided into individual and family factors, college factors, and employment preparation behavior. Individual and family factors include gender, age, parents' education level, and socioeconomic background. Most studies report that men's employment outcomes are better than those of women (Park and Cheon 2009) because Korean companies tend to believe that men deliver better performance in the labor market. Further, a higher age is typically more likely to lead to a higher wage level and greater job stability; however, it has a negative effect beyond a certain age. However, Nam (2006) reported that as they age, the likelihood of young people gaining employment gradually declines. Korean and overseas studies show different results for parents' education level and income. According to an overseas study, when parents' education and income are higher, their children are more likely to secure a better job (Joyce and Neumark 2001). Meanwhile, a Korean study reports that as Korea's college entrance rate hovers above $70 \%$, parents' education level or income does not have a significant effect on their children's college entrance rate, and it is more likely that young people may find the jobs they were expecting when they entered college.

Second, college factors include choice of study major and college location. Liberal arts and social science majors have been found to be less likely to lead to employment than engineering majors are, while social science graduates' employment conditions are worse than are those of engineering graduates (Abel et al. 2014). Moreover, multiple majors (e.g., double majors, minor majors, interdepartmental majors) do not help young people find a job (Hwang and Baek 2008). Finally, medicine and pharmacy majors are more likely to find a job than liberal arts majors are, since the former are related to specific qualifications in specialized areas (Park and Cheon 2009).

Third, young people's employment preparation behavior and competencies influence their employment outcomes. Employment preparation behavior refers to the preparatory process in which an individual builds his or her competencies to find a preferred job, such as collecting information on potential jobs (Lee and Lee 2009). Variables such as grade point average (GPA), learning a foreign language, certificate acquisition, job experience, job information gathering, job fair attendance, and application submissions are variables of employment preparation behavior (Mano-Negrin and Tzafrir 2004; Mau and Kopischke 2001). These behaviors are known to positively affect employment outcomes (Light 2001; Ruhm 1997).

Job search theory is based on the premise that the amount of market information job-seekers acquire is directly related to the amount of effort they expend doing so. The harder a job-seeker tries to prepare for a job, the more likely he or she is to find employment (Farkas and England 1985). The same is true if a job-seeker searches for a job earlier than others do (Reid 1972). Additionally, human capital theory argues that the productivity gained from education, job training, and job experience accumulates human capital and thus leads to greater compensation (Burt 1997). Meyer and Wise (1982) found that young people's job experience during college has a positive effect on their wages after graduation (cf. Hwang and Baek 2008).

Complementary to the factors above, this study considers on-the-job training and self-esteem as additional variables. On-the-job training has recently been suggested as a way in which to resolve the high youth unemployment problem. This training links university education with job experience, enhancing graduates' contextual knowledge as well as their workplace and social readiness. Not only does job experience improve students' confidence, self-awareness, social skills, and job-specific knowledge, it also provides them with effective employment opportunities. Korea recently reinforced its on-the-job training (internship) requirements for unemployed young people, to resolve the mismatch between available jobs and jobseekers in the labor market (Jung and Cho 2018).

Some studies have also found that effective job performance relies more on non-cognitive personality traits than on cognitive skills (Heckman and Rubinstein 2001; 
Jackson 2006). These studies argue that non-cognitive skills have a positive effect on acquiring a job and achieving economic success. Therefore, both cognitive and noncognitive skills (e.g., self-esteem) need to be improved to develop the skill sets required by the labor market. Self-esteem is the belief and trust that individuals have in themselves, which develops through interactions with the external environment. Rosenberg (1965) stated that selfesteem is an overall judgment that leads to an individual's self-worth, self-respect, and self-acceptance. Individuals with higher self-esteem are more likely to be confident in their ability than those with lower self-esteem (Schwarz and Clore 2007), have a firm belief that their effort will pay off (Campbell 1990), and be less vulnerable to emotional pain or depression (Brown 2010; Steele et al. 1993). Therefore, when low employment and economic growth persist and the unemployment rate remains high, the importance of self-esteem is strongly emphasized because it promotes in young people a strong spirit, which enables them to persevere when searching for a job.

\subsection{Young people's escape from unemployment and transition into the labor market}

Before Korea, other countries studied young people's escape from unemployment and transition into their first job. The process in which young people transition from unemployment to employment is significant as it means that they have escaped a socially and financially unstable position, and taken their first step toward financial independence and career development.

Lynch (1989) analyzed the transition of young people from being unemployed to employed and found that the longer young people remain unemployed, the less likely they are to escape unemployment. Lynch added that local labor demand conditions and human capital investment are important factors influencing unemployment duration.

Van den Berg and Van Ours (1999) analyzed the degree to which the escape rate varies with unemployment duration and observed that a negative duration dependence appears earlier for young women than for young men. Thus, young women experience a stigma associated with unemployment relatively earlier than young men do. Biggeri et al. (2001) identified the effect of undergraduate programs on students' first jobs and found that individual characteristics and college programs influence the transition time to the labor market. Salas-Velasco (2007) researched factors affecting the first jobs of young people and found that individual characteristics such as academic level and socioeconomic background as well as an individual's activeness in searching for a job increase his or her chances of finding a first job.
Studies of Korea's youth unemployment have been conducted since 2000, facilitated by the regular publication of data on this topic by the Korean Labor and Income Panel, Youth Panel, Graduates Occupational Mobility Survey, and Korean Education and Employment Panel, among others. Based on their study of people aged 15-29 and data from the Korean Labor and Income Panel in 2000, for example, Ahn and Hong (2002) found that the average unemployment period is 15.5 months. Moreover, they observed that as the unemployment period lengthens, the possibility of escaping unemployment decreases and that women are more likely to escape unemployment than men are.

Ryu (2003) used the 2001 Youth Panel Survey's 1st year data to investigate the time it takes rural university graduates to find their first job. The results showed that it takes 4-year college graduates 9.7 months, on average, to find their first job, while graduates of universities in the Seoul metropolitan area take 7.9 months and graduates of rural universities 10.5 months. Furthermore, female and 4-year university graduates are more likely to escape unemployment than are male and 2-year college graduates and a higher household income leads to a higher likelihood of escaping unemployment. Lee et al. (2005) analyzed how 4-year university graduates find their first job, based on Statistics Korea's 2004 additional data on young people in the economically active population. Their results showed that these graduates take 6.9 months, on average, to find their first job and that this period increases for medicine and pharmacy, arts and sports, liberal arts, engineering, and natural sciences graduates, in that order. Additionally, women are more likely to escape unemployment than men are, while full-time employment and part-time job experience during college increase the possibility of graduates finding their first job.

\section{Subjects and variables 3.1 Subjects}

This study uses data on middle and high school (general and vocational) third-grader cohorts from the Korean Education and Employment Panel, which has conducted 11 longitudinal surveys since 2004. Data from this panel are administered by a government-funded research institute, and are currently used for conducting mid-to-long run research projects on behalf of the government. The sample for this study is stratified into 15 regions (Seoul, six metropolitan cities, and eight provinces, excluding Jeju Island). 4175 middle and high schools across the country were selected through stratified sampling, and multistage sampling was applied at the school-classstudent levels. The sample has nationwide representativeness for middle and high school students. 
In particular, this study integrates and uses the eighth (2011) to the 11th (2014) surveys that provide data on those aged 25 to 28 , as of 2015 , which is the latest data available on their college life, employment preparation, and transition to the labor market. Those in the middle school third-grader cohort were approximately 25 years in the 11th year and 2-year college graduates and female university students who had not taken a semester off in this cohort had graduated from college and started finding jobs (see the Table 1). Additionally, around this time, college students in the high school third-grader cohort who had finished their military service or taken semesters off had graduated and found a job.

\subsection{Data and variables}

Table 2 presents the study variables. The two dependent variables are employment status and unemployment exit duration. Regarding employment status, only those who answered "yes" to both "permanent" and "full-time" jobs are treated as employed. Unemployment exit duration refers to the time it took college graduates to find their first job after graduation. To calculate this period, their graduation month (February 2012) is subtracted from the month in which they started their first job. Where an individual was employed before graduation, their unemployment exit duration is shown as " 0 months."

The independent variables are divided into individual and college characteristics, self-management competencies, and employment preparation behavior. Gender and cohort are individual characteristics. The latter is used to confirm the age of college graduates (i.e., those in the high school third-grader cohort are 3 years older than those in the middle school third-grader cohort). College characteristics include type of college (2-year college, 4-year university), study major, and college location. College majors were divided into liberal arts, social sciences, education, engineering, natural sciences, medicine and pharmacy, and arts and sports, while the location was categorized into Seoul, Gyeonggi Province, Gyeongsang Province, Jeolla Province, and Chungcheong Province. Location ${ }^{1}$ was added as a variable due to an increase in young people's migration between cities and provinces in Korea, particularly those aged from 25 to 29 . Young people's migration across regions is considered to have an effect on their escape from unemployment, as it is strongly oriented toward the Seoul metropolitan area. In addition, parents' education level and income, identified

\footnotetext{
${ }^{1}$ Korea comprises of 17 administrative areas. These may also be broadly categorized as the Capital Area (which includes Seoul, Incheon, and Gyeonggi Province), the Gyeongsang Area, the Jeolla Area, and the Chungcheong Area.
}

from previous studies, were excluded, as they had many missing values due to the nature of panel data.

Self-esteem was used to measure self-management competencies. Self-esteem refers to considering oneself to be worthwhile and valuable, and believing that one is good enough to achieve something (Rosenberg 1965). It has a positive effect on an individual's achievement of goals. Lastly, employment preparation behavior before college graduation was examined. Employment preparation behavior variables identified from the panel included several interviews with the advisor professor, on-the-job training, GPA, job-seeking experience, and activeness in job-seeking. Interviews with the advisor professor are mostly consultations about career and academic work, and a higher number of interviews mean that an individual has greater interest and is more active in his/her career path. On-the-job-training (internship) refers to a curriculum in which a student works at a company and learns work practices for a certain period during college. In Korea, students can select and experience this as employment preparation behavior through vocational experience. Since GPAs are different across colleges, this study divided the average GPA by the maximum, and converted it into points out of a possible 100 . Activeness in job-seeking was calculated from the sum of the number of times the subjects participated in 15 employment preparation activities, including job training and consultation with the employment agency.

Although the original data consisted of a total of 4598 observations, cases with missing values for any of the variables used for analysis were discarded. Therefore, a total of 426 cases were used in the analysis.

\subsection{Research method}

This study uses the survival analysis method. A survival analysis statistically analyses data during the period leading up to a certain event (Machin et al. 2006). This statistical method thus analyses the period during which subjects stay in a certain state and estimates the factors affecting such a period as well as the intensity of the factors' effects.

For this analysis, this study uses the Kaplan-Meier analysis and Cox proportional hazards model. The Kaplan-Meier analysis estimates and verifies the survival probability at each point in time, regardless of the size of a sample, as long as the survival period of each subject is provided, including censored cases. The method calculates the probability of college graduates escaping unemployment after graduation over time. Specifically, the time observed from a certain point to the occurrence of a specific event is referred to as the survival time. Some college graduates remained unemployed until the end of the study, in which case the length of the time they remained unemployed 


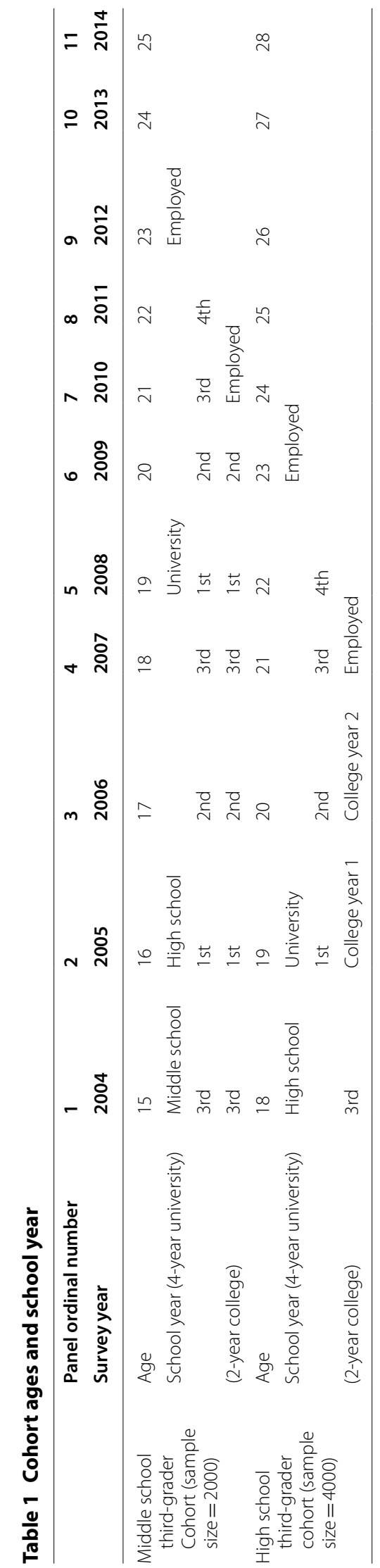


Table 2 The composition and explanation of the variables

\begin{tabular}{|c|c|}
\hline Variable & Variable number \\
\hline \multicolumn{2}{|l|}{ Dependent variables } \\
\hline Employment status & Unemployed $=0$, employed $=1$ \\
\hline Unemployment exit duration (month) & The first job start month_February 2012 (graduation month) \\
\hline \multicolumn{2}{|l|}{ Independent variables } \\
\hline \multicolumn{2}{|l|}{ Individual and college characteristics } \\
\hline Gender & Male $=1$, female $=0$ \\
\hline Cohort & $\begin{array}{l}\text { Middle school third grader }=1 \text {, vocational high school third grader }=2 \text {, general high school third grader } 3 \\
\text { (dummy) }\end{array}$ \\
\hline Type of college & 2-year college $=0$, 4-year university $=1$ \\
\hline Major & $\begin{array}{l}\text { Liberal arts }=1 \text {, social sciences }=2 \text {, education }=3 \text {, engineering }=4 \text {, natural sciences }=5 \text {, medicine and } \\
\text { pharmacy }=6 \text {, arts and sports (dummy) }\end{array}$ \\
\hline Location of college & $\begin{array}{l}\text { Seoul }=1 \text {, Gyeonggi Province }=2 \text {, Gyeongsang Province }=3 \text {, Jeolla Province }=4 \text {, Chungcheong Province } \\
\quad(\text { dummy) }\end{array}$ \\
\hline Self-management competencies & Self-esteem (five-point scale) \\
\hline \multicolumn{2}{|l|}{ Employment preparation behavior } \\
\hline Interview with advisor professor & Number of interviews (career) with advisor professors \\
\hline On-the-job training & $\mathrm{No}=0$, yes $=1$ \\
\hline GPA & Latest semester's GPA, out of 100 \\
\hline Job-seeking experience & $\mathrm{No}=0$, yes $=1$ \\
\hline Activeness in job-seeking & Various job-seeking activities (15 activities, 0 point $\sim 15$ point) \\
\hline
\end{tabular}

could not be observed. These were treated as censored data showing that they were still unemployed at the end of the study. When survival times are organized in ascending order, and the unemployment period of $n$ college graduates is divided by $q, \mathrm{t}_{0} \leqq \mathrm{t}_{1} \leqq \ldots \leqq \mathrm{t}_{\mathrm{q}}\left(\mathrm{t}_{0}=0\right)$. The Kaplan-Meier survival function is derived as follows:

$$
\hat{s}(t)=\prod_{t_{j} \leq t} \hat{p}_{j}
$$

where $P_{j}$ denotes the number of surviving individuals at time $t_{j}$ divided by the number of surviving individuals at time $t_{j}-1$. Under the assumption that the observations of the survival of individuals occur at discrete times, the number of surviving subjects at $t_{j}-1$, just before $t_{j}$, is assumed to be $n_{j}$ and the number of young people who survive at time $t_{j}-1$ and escape unemployment at time $t_{j}$ is assumed to be $h_{j}$. In this case, the Kaplan-Meier survival function is expressed as follows:

$$
\hat{s}(t)=\prod_{j=1}^{N}\left[\frac{n_{j}-h_{j}}{n_{j}}\right]
$$

Additionally, to analyze the effects of the explanatory variable on hazards, this study uses the Cox hazards model. The Cox hazards function is given as follows:

$$
\mathrm{h}(\mathrm{t})=\mathrm{h}_{0}(\mathrm{t}) \exp \left(\beta_{1} \chi_{1}+\cdots+\beta_{\mathrm{k}} \chi_{\mathrm{k}}\right)
$$

where $\mathrm{h}(\mathrm{t})$ is the hazards function when the covariance is considered (the function of $\mathrm{t}$ and $\mathrm{X}$ ); $\mathrm{h}_{0}(\mathrm{t})$ is the baseline hazards function, which is the value of the hazards function when all covariance values are 0 . This refers to the instantaneous hazard rate given to a subject by default if there is no effect of covariance (a function of $t$ only); $\beta$ is Regression coefficient.

A survival analysis assumes that the hazards of an individual's event occurrence are all the same; however, in reality, an individual's characteristics could affect the survival period. In such a case, individuals can be stratified into groups and compared by estimating their survival function. However, a limitation of this method is that it cannot be applied if there are two or more independent variables. The Cox proportional hazards regression model is a regression analysis method that uses the nonparametric model, which overcomes this limitation (Cox 1972). The model enables an analysis that considers right-censored cases and is mainly used when it is not necessary to make an assumption about the distribution of the probability of transitioning from unemployment to employment with respect to time.

This study codes unemployment exit duration as "0 months" for college graduates employed before or at graduation in February 2012, resolving the problem by being censored on the left. If graduates were not employed for 34 months after graduation (December 2014), the last observation point, they are censored on 
Table 3 General characteristics of the subjects

\begin{tabular}{|c|c|c|c|c|c|c|}
\hline & \multicolumn{2}{|c|}{$\begin{array}{l}\text { Middle school third-grader } \\
\text { cohort }\end{array}$} & \multicolumn{2}{|c|}{ High school third-grader cohort } & \multicolumn{2}{|l|}{ Total } \\
\hline & Frequency & $\%$ & Frequency & $\%$ & Frequency & $\%$ \\
\hline \multicolumn{7}{|l|}{ Gender } \\
\hline Men & 70 & 28.2 & 157 & 88.2 & 227 & 53.3 \\
\hline Women & 178 & 71.8 & 21 & 11.8 & 199 & 46.7 \\
\hline Total & 248 & 100.0 & 178 & 100.0 & 426 & 100.0 \\
\hline \multicolumn{7}{|l|}{ Type of college } \\
\hline 2-year college & 74 & 29.8 & 32 & 18.0 & 106 & 24.9 \\
\hline 4-year university & 174 & 70.2 & 146 & 82.0 & 320 & 75.1 \\
\hline Total & 248 & 100.0 & 178 & 100.0 & 426 & 100.0 \\
\hline \multicolumn{7}{|l|}{ Major } \\
\hline Liberal arts & 17 & 6.9 & 8 & 4.5 & 25 & 5.9 \\
\hline Social sciences & 75 & 30.2 & 39 & 21.9 & 114 & 26.8 \\
\hline Education & 29 & 11.7 & 4 & 2.2 & 33 & 7.7 \\
\hline Engineering & 56 & 22.6 & 79 & 44.4 & 135 & 31.7 \\
\hline Natural sciences & 24 & 9.7 & 17 & 9.6 & 41 & 9.6 \\
\hline Medicine and pharmacy & 21 & 8.5 & 11 & 6.2 & 32 & 7.5 \\
\hline Arts and sports & 26 & 10.5 & 20 & 11.2 & 46 & 10.8 \\
\hline Total & 248 & 100.0 & 178 & 100.0 & 426 & 100.0 \\
\hline \multicolumn{7}{|l|}{ Location of college } \\
\hline Seoul & 32 & 12.9 & 22 & 12.4 & 54 & 12.7 \\
\hline Gyeonggi, Incheon, and Gangwon & 37 & 14.9 & 44 & 24.7 & 81 & 19.0 \\
\hline Gyeongsang & 80 & 32.3 & 60 & 33.7 & 140 & 32.9 \\
\hline Jeolla & 44 & 17.7 & 13 & 7.3 & 57 & 13.4 \\
\hline Chungcheong & 55 & 22.2 & 39 & 21.9 & 94 & 22.1 \\
\hline Total & 248 & 100.0 & 178 & 100.0 & 426 & 100.0 \\
\hline
\end{tabular}

the right. A statistical analysis of the survival period was conducted by using SPSS 23.0.

\section{Results and discussion}

\subsection{Characteristics of subjects}

As shown in Table 3, the percentages of men and women were similar, with $53.3 \%$ men $(n=227)$. However, there was a gap in the gender distribution depending on the cohort; men accounted for $88.2 \%$ of the high school third-grader cohort and women accounted for $71.8 \%$ of the middle school third-grader cohort. This is because men in Korea are generally 3 years behind women after graduation because of their mandatory military service. Regarding college type, the percentage of 4-year university graduates was higher at $75.1 \%(\mathrm{n}=320)$ compared with 2-year graduates at $24.9 \%(n=106)$. The percentage of 2-year college graduates in the middle school thirdgrader cohort (29.8\%) was higher than that in the high school third-grader cohort (18.0\%).

The percentages regarding study majors occurred in the order of engineering, social sciences, arts and sports, natural sciences, and education. While the percentage of social sciences and education majors in the middle school third-grader cohort was higher than that in the high school third-grader cohort, the percentage of engineering majors in the high school third-grader cohort was relatively high. Finally, regarding college location, the percentage of Jeolla Province was higher in the middle school third-grader cohort, while the percentages of graduates from colleges in Gyeonggi, Incheon, and Gangwon were higher in the high school third-grader cohort.

\subsection{Graduates' unemployment exit duration}

Graduates who did not search for a job were excluded from the Kaplan-Meier survival analysis, leaving 426 subjects. Of these, 41 (9.6\%) remained unemployed even though they searched for a job until the end of the analysis period, but could not find employment.

As shown in Table 4, college graduates, whose unemployment exit duration was 0 months because they found a job before or at graduation, accounted for $34.7 \%$ (148) of the total. Regarding unemployment exit duration, it took $50 \%$ of all subjects about 2 months to find a job after graduation, while $70 \%$ of them took 8 months or 
Table 4 Survival rate for each unemployment exit duration

\begin{tabular}{|c|c|c|c|c|c|}
\hline \multirow[t]{2}{*}{ Time (period/month) } & \multirow[t]{2}{*}{ Number of events } & \multicolumn{2}{|c|}{ Accumulated survival rate for time } & \multirow{2}{*}{$\begin{array}{l}\text { Number of accumulated } \\
\text { events }\end{array}$} & \multirow{2}{*}{$\begin{array}{l}\text { Number } \\
\text { of remaining } \\
\text { cases }\end{array}$} \\
\hline & & Estimate & $\overline{\text { Standard error }}$ & & \\
\hline 0 & 148 & 0.653 & 0.023 & 148 & 278 \\
\hline 1 & 41 & 0.556 & 0.024 & 189 & 237 \\
\hline 2 & 30 & 0.486 & 0.024 & 219 & 207 \\
\hline 3 & 17 & 0.446 & 0.024 & 236 & 190 \\
\hline 4 & 18 & 0.404 & 0.024 & 254 & 172 \\
\hline 5 & 13 & 0.373 & 0.023 & 267 & 159 \\
\hline 6 & 11 & 0.347 & 0.023 & 278 & 148 \\
\hline 7 & 14 & 0.315 & 0.022 & 292 & 134 \\
\hline 8 & 9 & 0.293 & 0.022 & 301 & 125 \\
\hline 9 & 3 & 0.286 & 0.022 & 304 & 122 \\
\hline 10 & 4 & 0.277 & 0.022 & 308 & 118 \\
\hline 11 & 5 & 0.265 & 0.021 & 313 & 107 \\
\hline 12 & 2 & 0.260 & 0.021 & 315 & 105 \\
\hline 13 & 11 & 0.232 & 0.021 & 326 & 94 \\
\hline$\ldots$ & $\ldots$ & & & & \\
\hline 34 & 1 & 0.108 & 0.016 & 375 & 41 \\
\hline
\end{tabular}

Table 5 Estimated average and median of college graduates' unemployment exit duration (Kaplan-Meier analysis)

\begin{tabular}{|c|c|c|c|c|c|}
\hline \multicolumn{3}{|l|}{ Average } & \multicolumn{3}{|l|}{ Median } \\
\hline \multirow[t]{2}{*}{ Estimate } & \multicolumn{2}{|c|}{$95 \%$ confidence interval } & \multirow[t]{2}{*}{ Estimate } & \multicolumn{2}{|c|}{$95 \%$ confidence interval } \\
\hline & $\begin{array}{l}\text { Lower } \\
\text { confidence } \\
\text { limit }\end{array}$ & $\begin{array}{l}\text { Upper } \\
\text { confidence } \\
\text { limit }\end{array}$ & & $\begin{array}{l}\text { Lower } \\
\text { confidence } \\
\text { limit }\end{array}$ & $\begin{array}{l}\text { Upper } \\
\text { confidence } \\
\text { limit }\end{array}$ \\
\hline 8.358 & 7.253 & 9.463 & 2.000 & 1.140 & 2.860 \\
\hline
\end{tabular}

less. One year after graduation, $75 \%$ had a job, and this percentage declined gradually over time. Around $10 \%$ of college graduates remained unemployed after 34 months.

The average time it took college graduates to escape unemployment was 8.35 months. The time it took the top $50 \%$ of all graduates to find a job (median) was about 2 months (Table 5). Figure 1 illustrates that the percentage of those who escaped unemployment declined rapidly after graduation and then fell more slowly over time. In other words, the longer that unemployment continued after graduation, the less likely it became that graduates would escape unemployment. Of the individual and college characteristics, women's unemployment exit duration (10.2 months) was longer than that of men (6.7 months; Table 6).

However, since the average period was greatly affected by outliers, it is more appropriate to examine the median of the accumulated survival rate (the accumulated percentage of those who remained unemployed)

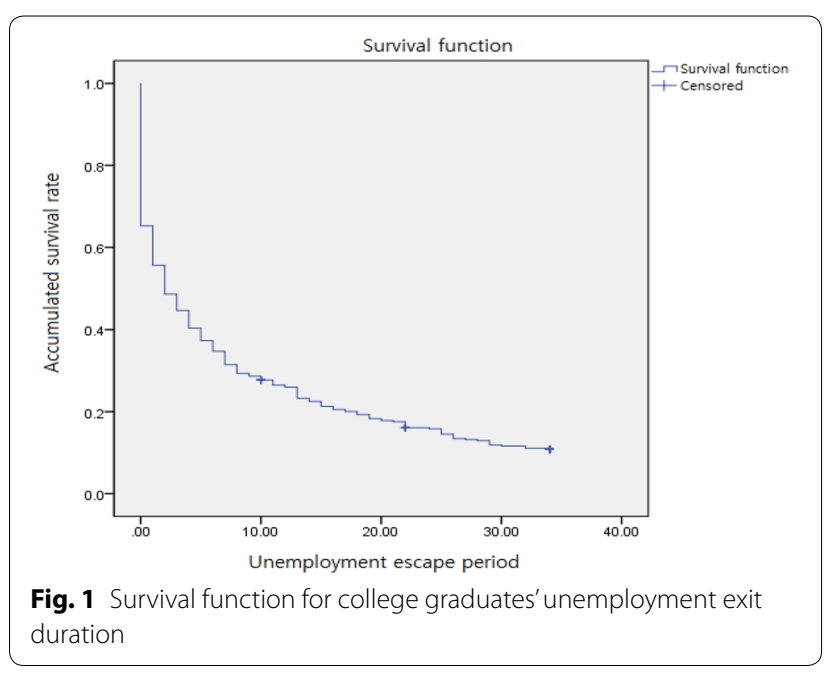

to determine the overall trend. In this case, women's unemployment exit duration median (4 months) was twice as long as that of men (2 months). These results were consistent with those from previous studies; it is believed that Korean businesses prefer men over women in recruitment, and women tend to invest more than men to enter the primary labor market, that has greater stability and more benefits.

Regarding college type, it took 2-year college graduates 6.8 months (median $=1$ month) and 4-year university graduates 8.8 months (median $=3$ months) to find a job. The unemployment exit duration of 2-year college 
Table 6 Estimated average and median unemployment exit duration based on the individual and college characteristics (Kaplan-Meier analysis)

\begin{tabular}{|c|c|c|c|c|c|c|c|}
\hline & \multicolumn{3}{|l|}{ Average } & \multicolumn{3}{|l|}{ Median } & \multirow[t]{3}{*}{ Log rank (Mantel-Cox) $X^{2}$} \\
\hline & \multirow[t]{2}{*}{ Estimate } & \multicolumn{2}{|c|}{$95 \%$ confidence interval } & \multirow[t]{2}{*}{ Estimate } & \multicolumn{2}{|c|}{$95 \%$ confidence interval } & \\
\hline & & $\begin{array}{l}\text { Lower } \\
\text { confidence } \\
\text { limit }\end{array}$ & $\begin{array}{l}\text { Upper } \\
\text { confidence } \\
\text { limit }\end{array}$ & & $\begin{array}{l}\text { Lower } \\
\text { confidence } \\
\text { limit }\end{array}$ & $\begin{array}{l}\text { Upper } \\
\text { confidence } \\
\text { limit }\end{array}$ & \\
\hline \multicolumn{8}{|l|}{ Gender } \\
\hline Men & 6.733 & 5.378 & 8.087 & 2.000 & 1.140 & 2.860 & \multirow[t]{3}{*}{$10.243^{* *}$} \\
\hline Women & 10.207 & 8.451 & 11.963 & 4.000 & 2.327 & 5.673 & \\
\hline Total & 8.358 & 7.253 & 9.463 & 2.000 & 1.140 & 2.860 & \\
\hline \multicolumn{8}{|l|}{ Cohort } \\
\hline Middle school third grader & 9.069 & 7.558 & 10.580 & 3.000 & 1.815 & 4.185 & \multirow[t]{4}{*}{-} \\
\hline $\begin{array}{l}\text { Vocational high school third } \\
\text { grader }\end{array}$ & 8.641 & 5.088 & 12.194 & 2.000 & 0.133 & 3.867 & \\
\hline General high school third grader & 6.940 & 5.189 & 8.692 & 2.000 & .313 & 3.687 & \\
\hline Total & 8.358 & 7.253 & 9.463 & 2.000 & 1.140 & 2.860 & \\
\hline \multicolumn{8}{|l|}{ Type of college } \\
\hline 2-year college & 6.829 & 4.800 & 8.859 & 1.000 & 0.000 & 2.259 & \multirow[t]{3}{*}{$3.967^{*}$} \\
\hline 4-year university & 8.866 & 7.563 & 10.169 & 3.000 & 1.949 & 4.051 & \\
\hline Total & 8.358 & 7.253 & 9.463 & 2.000 & 1.140 & 2.860 & \\
\hline \multicolumn{8}{|l|}{ Major } \\
\hline Liberal arts & 12.480 & 7.622 & 17.338 & 7.000 & 2.104 & 11.896 & \multirow{8}{*}{$\begin{array}{l}\text { Liberal arts/engineering: } 6.845^{* *} \\
\text { Liberal arts/medicine and phar- } \\
\text { macy: } 4.075^{*} \\
\text { Social sciences/engineering: } \\
7.302^{* *} \\
\text { Arts/engineering: } 8.699^{* *}\end{array}$} \\
\hline Social sciences & 9.932 & 7.684 & 12.180 & 4.000 & 1.909 & 6.091 & \\
\hline Education & 7.091 & 3.841 & 10.341 & 1.000 & 0.000 & 2.535 & \\
\hline Engineering & 6.029 & 4.290 & 7.767 & 1.000 & & & \\
\hline Natural sciences & 6.805 & 3.476 & 10.134 & 2.000 & 0.000 & 4.689 & \\
\hline Medicine and pharmacy & 6.594 & 2.931 & 10.256 & 2.000 & 0.625 & 3.375 & \\
\hline Arts and sports & 12.674 & 8.704 & 16.644 & 6.000 & 0.461 & 11.539 & \\
\hline Total & 8.358 & 7.253 & 9.463 & 2.000 & 1.140 & 2.860 & \\
\hline \multicolumn{8}{|l|}{ Location of college } \\
\hline Seoul & 10.945 & 7.204 & 14.687 & 4.000 & 1.942 & 6.058 & Seoul/Gyeonggi, \\
\hline $\begin{array}{l}\text { Gyeonggi, Incheon, and Gang- } \\
\text { won }\end{array}$ & 6.346 & 4.231 & 8.460 & 2.000 & 1.143 & 2.857 & \multirow{5}{*}{$\begin{array}{l}\text { Incheon, and Gangwon: 4.853* } \\
\text { Jeolla/Gyeonggi, Incheon and } \\
\text { Gangwon: 4.958* }\end{array}$} \\
\hline Gyeongsang & 7.790 & 5.936 & 9.645 & 2.000 & 0.949 & 3.051 & \\
\hline Jeolla & 10.343 & 7.073 & 13.613 & 4.000 & 1.543 & 6.457 & \\
\hline Chungcheong & 8.272 & 5.979 & 10.565 & 3.000 & 1.104 & 4.896 & \\
\hline Total & 8.358 & 7.253 & 9.463 & 2.000 & 1.140 & 2.860 & \\
\hline
\end{tabular}

${ }^{*} p<0.10,{ }^{*} p<0.05,{ }^{* *} p<0.01,{ }^{* *} p<0.001$

graduates was shorter than that of 4-year university graduates. Two-year colleges focused more on vocational training for employment than 4-year colleges, and graduates from 2-year colleges got jobs earlier than those from 4 -year colleges. Regarding majors, unemployment exit duration increased in the order of engineering, medicine and pharmacy, natural sciences, education, social sciences, liberal arts, and arts and sports. According to the log rank test, there were statistically significant differences in unemployment exit duration between engineering and liberal arts $\left(\mathrm{X}^{2}=6.845, \mathrm{p}<0.05\right)$, engineering and social sciences $\left(\mathrm{X}^{2}=7.302, \mathrm{p}<0.05\right)$, engineering and arts $\left(\mathrm{X}^{2}=8.699, \mathrm{p}<0.05\right)$, and liberal arts and medicine and pharmacy $\left(\mathrm{X}^{2}=4.075, \mathrm{p}<0.01\right)$. These results can be attributed to the fact that medicine and pharmacy, engineering, and education majors have an advantage in getting a job, as their qualifications or skills can be linked to a professional occupation. In addition, arts students took the longest to escape from unemployment, partly because the number of available jobs in arts is small, but mainly because there are many types of freelancing jobs in arts that are not widely reflected in Korea's employment rate. 
Table 7 Analysis of the determinants of college graduates' escape from unemployment

\begin{tabular}{|c|c|c|c|c|c|c|c|c|}
\hline & \multicolumn{2}{|l|}{ Model 1} & \multicolumn{2}{|l|}{ Model 2} & \multicolumn{2}{|l|}{ Model 3} & \multicolumn{2}{|l|}{ Model 4} \\
\hline & B & $\operatorname{Exp}(B)$ & B & $\operatorname{Exp}(B)$ & B & $\operatorname{Exp}(B)$ & B & $\operatorname{Exp}(B)$ \\
\hline Gender $($ male $=1)$ & -0.157 & 0.854 & -0.162 & 0.851 & -0.188 & 0.829 & -0.186 & 0.831 \\
\hline \multicolumn{9}{|l|}{ Cohort (dummy = general high school third grader) } \\
\hline Middle school third grader & -0.065 & 0.937 & -0.043 & 0.958 & 0.089 & 1.093 & 0.151 & 1.163 \\
\hline Vocational high school third grader & -0.151 & 0.860 & -0.135 & 0.874 & -0.139 & 0.870 & -0.075 & 0.928 \\
\hline Type of college (4-year university $=1$ ) & -0.191 & 0.826 & -0.182 & 0.834 & 0.036 & 1.036 & 0.048 & 1.049 \\
\hline \multicolumn{9}{|l|}{ Major (dummy = arts and sports) } \\
\hline Liberal arts & 0.022 & 1.022 & 0.087 & 1.090 & -0.355 & 0.701 & -0.191 & 0.826 \\
\hline Social sciences & 0.265 & 1.304 & 0.268 & 1.308 & -0.069 & 0.933 & -0.032 & 0.968 \\
\hline Education & $0.551^{*}$ & 1.735 & $0.588^{*}$ & 1.800 & 0.398 & 1.489 & 0.515 & 1.673 \\
\hline Engineering & $0.496^{*}$ & 1.643 & $0.495^{*}$ & 1.640 & 0.195 & 1.215 & 0.242 & 1.274 \\
\hline Natural sciences & $0.471^{*}$ & 1.601 & 0.450 & 1.569 & 0.170 & 1.185 & 0.201 & 1.223 \\
\hline Medicine and pharmacy & 0.436 & 1.547 & 0.469 & 1.598 & 0.261 & 1.298 & 0.368 & 1.445 \\
\hline \multicolumn{9}{|l|}{ Location of college (dummy= Chungcheong) } \\
\hline Seoul & -0.244 & 0.784 & -0.240 & 0.787 & -0.194 & 0.824 & -0.174 & 0.840 \\
\hline Gyeonggi, Incheon, Gangwon & 0.048 & 1.049 & 0.079 & 1.082 & 0.084 & 1.088 & 0.118 & 1.126 \\
\hline Gyeongsang & -0.020 & 0.980 & -0.003 & 0.997 & -0.110 & 0.896 & -0.082 & 0.921 \\
\hline Jeolla & -0.258 & 0.772 & -0.227 & 0.797 & -0.251 & 0.778 & -0.226 & 0.798 \\
\hline Self-esteem & & & $0.188^{*}$ & 1.207 & & & $0.290^{* *}$ & 1.336 \\
\hline The number of interviews with advisor professors (career) & & & & & -0.019 & 0.981 & -0.022 & 0.978 \\
\hline On-the-job training during college & & & & & 0.135 & 1.145 & 0.100 & 1.105 \\
\hline GPA & & & & & -0.012 & 0.988 & $-0.014^{\#}$ & 0.986 \\
\hline Job-seeking experience & & & & & $0.961^{* * *}$ & 2.614 & $1.059 * * *$ & 2.882 \\
\hline Activeness in job-seeking & & & & & $-0.101^{* *}$ & 0.904 & $-0.111^{* *}$ & 0.895 \\
\hline$-2 \log L$ & 4047.844 & & 4042.559 & & 2740.309 & & 2732.077 & \\
\hline Sample size & 426 & & 426 & & 426 & & 426 & \\
\hline
\end{tabular}

${ }^{\#}<0.10,{ }^{*}<0.05,{ }^{* *}<0.01,{ }^{* * *}<0.001$

Finally, there were differences in unemployment exit duration based on college location. College graduates in Seoul (average $=10.9$ months, median $=4$ months) and in Jeolla (average $=10.3$ months, median $=4$ months) had a longer unemployment exit duration than those in Gyeonggi, Incheon, and Gangwon (average $=6.3$ months, median $=2$ months). Seoul is Korea's capital and is home to many large companies and the primary labor market. The results seem to reflect that many young people want to find a job in companies located in Seoul, and subsequently spend more time preparing for it. There were no statistically significant differences based on cohort.

\subsection{Determinants of college graduates' escape from unemployment}

The Cox proportional hazards analysis was conducted by using four models. Model 1's inputs were the individual and college variables such as gender, cohort, type of college, major, and location of college, while Model 2 added self-esteem to the inputs of Model 1 . Model 3 added employment preparation behavior to Model 1 as an independent variable. Finally, Model 4's inputs included all the variables, namely individual and college variables, self-management competencies, and employment preparation behavior.

The results of Model 1 in Table 7 show that study major affected college graduates' unemployment exit duration. Specifically, education graduates were 1.73 times more likely to escape unemployment than were arts and sports graduates, while engineering (natural sciences) graduates were 1.64 (1.60) times more likely to escape. Gender, cohort, type of college, and location of college did not have statistically significant effects on the probability of escaping unemployment.

The results of Model 2 show that education and engineering graduates were still more likely to escape unemployment than were arts and sports graduates, while the group with high self-esteem was 1.20 times more likely to escape unemployment than was the group with low selfesteem. By contrast, after including employment preparation behavior (Model 3), it was found that job-seeking 
preparation behavior and activeness in job-seeking had a significant effect. Those who performed job-seeking activities were 2.61 times more likely to escape unemployment than those who did not. However, activeness in employment preparation showed negative results. Specifically, these activities made it 0.90 times less likely that a graduate would escape from unemployment, implying that graduates who performed many job-seeking activities did so without a clear employment strategy. Hence, their activeness did not have a positive effect on their employment, instead prolonging their employment preparation period.

Finally, when all the variables were included as inputs (Model 4), it was found that young people's self-esteem helped them escape unemployment sooner (1.33 times) and that job-seeking activities positively affected escaping unemployment (2.88 times). However, GPA (0.98 times) and activeness in job-seeking (0.89 times) made it difficult to escape unemployment. A high GPA suggests that a candidate studied diligently to find a better-quality job. In other words, students with higher GPAs have higher expectations about their first job, and delay their graduation to find a job that meets their expectations. As a result, their employment preparation is prolonged.

\section{Conclusion}

This study explored the time it takes college graduates to escape unemployment as well as the factors that affect such an escape given that youth unemployment is a serious problem in Korea. It identified the employment preparation behavior and unemployment exit durations of those who graduated college in 2012 to reflect the status of the youth labor market and propose solutions and policy options to ease the youth unemployment problem.

First, college graduates showed different employment preparation behavior depending on their individual and college characteristics. While women focused more on GPA than men did, men were more active in employment preparation behavior, including job training, asking for jobs, participating in job fairs, acquiring certificates, and uploading résumés. Furthermore, on-the-job training was found to be conducted actively in 2-year colleges and certain majors. This resulted in differences in on-the-job training, depending on the major and college characteristics. Specifically, liberal arts and social science majors in 4-year universities had little on-the-job training experience, meaning that their understanding and preparation for workplace life and jobs were much lower than those of engineering, natural sciences, education, and medicine and pharmacy majors.

Second, because college graduates' unemployment periods are prolonged, it lowered their possibility of escaping unemployment. Such results are consistent with those of Lee et al. (2005), who showed that the probability of escaping unemployment is highest immediately after graduation, but decreases over time, although more information is obtained from job searching. Furthermore, the probability remains low after a certain length of time. The time it takes to find a job after graduation is an indicator of the ease of transition into the labor market, with an increase in the job-seeking period causing serious social and economic problems. These results indicate that a longer job-seeking period reduces an individual's confidence in job-seeking activities and that the stigma related to unemployment makes it more difficult to find a job (Ahn and Hong 2002; Lynch 1989).

Third, self-esteem, one of young people's self-management competencies, is an important factor in increasing the possibility of escaping unemployment. The unemployment exit duration of those with high self-esteem during college was significantly shorter than for those with low self-esteem, with self-esteem increasing the probability of escaping from unemployment. These results are consistent with those of previous studies showing that an individual's satisfaction and happiness is affected by his or her subjective perception and state of life (Jung and Kang 2015).

Fourth, the results of the Cox proportional hazards model analysis found that although job-seeking activities have a positive effect on escaping unemployment, indiscriminate employment preparation has a negative effect. The employment preparation behavior variable used in this study thus raises a question about behavior during college years, showing that performing many job-seeking activities does not necessarily reduce the time it takes graduates to find their first job.

Based on these results, this study can draw the following implications. First, there is a need to overhaul college curricula and education methods to include job experience and on-the-job training so that young people are better prepared for the labor market. The gap between university education and job training has long been considered to be a shortcoming of university education in Korea. An examination of the curriculum and system is currently needed to provide more diverse on-the-job training and work experience programs, so that young people can understand and prepare for the labor market more realistically. This process is expected to have a positive effect on accumulation and formation of human capital.

Second, a prolonged unemployment period continues to prevent young people from finding a job, which may result in individuals giving up on finding a job entirely. Thus, detailed support is needed during the unemployment period based on the job-seeker's circumstances 
(e.g., helping them lower their job expectations). Additionally, young people need to strive to find strategic and faster entries into the labor market by searching for jobs they hope to get. While it is difficult to fix this problem in the near future, due to the recent worsening of Korea's employment situation, it is necessary to put in place policies that can lower entry barriers to the labor market by alleviating corporate size and working requirements to tackle a dual structure (Yoon et al. 2017; Moon 2018).

Third, unemployment exit duration and the possibility of escaping unemployment are determined significantly by an individual's subjective thoughts and psychological perception. Individuals should have a level of self-esteem that enables them to exert their self-leadership. Furthermore, the education system and social institutions should provide education, counselling, and consulting opportunities for young people that enable them to experience small successes as well as reinforce their belief and trust in themselves.

Finally, young people's indiscriminate pursuit of building up qualifications, sometimes as many as seven or eight, creates issues in their transition from the education system into the labor market, such as increasing their private education costs, raising the number of semesters deferred and number of students who delay their graduation, and prolonging the transition period into their first job. However, this pursuit of qualifications and quantitative increase in employment preparation do not significantly reduce young people's unemployment period.

Currently, the Korean government advocates job creation, and focuses national resources on solving young people's employment problem. The government also dedicates itself to not only creating jobs in companies but also improving the labor market's structure, which has a complex impact. In this regard, it is important to make a more fundamental and comprehensive shift in this direction, and social and policy efforts should be made to raise the right awareness about labor, so that young people get the jobs they seek.

\section{Authors' contributions}

Both authors read and approved the final manuscript.

\section{Author details}

${ }^{1}$ Vocational Education and Training Institute, Korea Polytechnics, 478, Munemi-ro, Bupyeong-gu, Incheon, South Korea. ${ }^{2}$ Graduate School of Human Resource Development, Sookmyung Women's University, \#1013, Sunheon-Gwan, Chungpa-Dong, Yongsan-Gu, Seoul, South Korea.

\section{Acknowledgements}

Not applicable.

\section{Competing interests}

The authors declare that they have no competing interests.

\section{Availability of data and materials}

The data that support the findings of this study are available at https://www. krivet.re.kr.

\section{Funding}

This work was supported by Global Research Network program through the Ministry of Education of the Republic of Korea and the National Research Foundation of Korea (NRF-2016S1A2A2912272).

\section{Publisher's Note}

Springer Nature remains neutral with regard to jurisdictional claims in published maps and institutional affiliations.

Received: 24 May 2018 Accepted: 3 April 2019

Published online: 26 April 2019

\section{References}

Abel, J.R., Deitz, R., Su, Y.: Are recent college graduates finding good jobs? Curr. Issues Econ. Fin. 20(1), 1-8 (2014)

Ahn, J., Hong, S.: Before and after the economic crisis: duration to first job of Korean young graduates. Korean J. Labour Econ. 25(1), 47-74 (2002)

Bae, G.: Changes in the socio-economic environment and reforms for the labor market's dual structure, presentation from the socio-economic policy forum (2017)

Biggeri, L., Bini, M., Grilli, L.: The transition from university to work: a multilevel approach to the analysis of the time to obtain the first job. J. R. Stat. Soc. Ser. A Stat. Soc. 164(2), 293-305 (2001)

Brown, J.D.: High self-esteem buffers negative feedback: once more with feeling. Cogn. Emot. 24(8), 1389-1404 (2010)

Burt, R.S.: The contingent value of social capital. Adm. Sci. Q. 42(2), 339-365 (1997)

Campbell, J.D.: Self-esteem and clarity of the self-concept. J. Pers. Soc. Psychol. 59(3), 538 (1990)

Cox, D.R.: Regression models and life-tables (with discussion). J. R. Stat. Soc. Ser. B Stat. Methodol. 34, 187-220 (1972)

Farkas, G., England, P.: Integrating the sociology and economics of employment, compensation, and unemployment. Res. Sociol. Work 3, 119-146 (1985)

Finnie, R.: The school-to-work transition of Canadian post-secondary graduates: a dynamic analysis. J. High. Educ. Policy Manag. 26(1), 35-58 (2004)

Heckman, J.J., Rubinstein, Y.: The importance of noncognitive skills: lessons from the GED testing program. Am. Econ. Rev. 91(2), 145-149 (2001)

Hong, K.: Determination of youth unemployment. J. Korean Econ. Anal. 24(2), 91-137 (2018)

Hwang, Y., Baek, B.: The determinants of youth labour market performance. J. Employ. Skills Dev. 11(2), 1-23 (2008)

ILO: Global employment trends for youth: a generation at risk. ILO Report, Geneva (2013)

ILO: Global employment trends for youth 2018. ILO Report, Geneva (2017)

Jackson, M.: Personality traits and occupational attainment. Eur. Sociol. Rev. 22(2), 187-199 (2006)

Joyce, M., Neumark, D.: School-to-work programs: information from two surveys. Monthly Labour Rev. 124, 38 (2001)

Jung, J., Cho, M.: Analyzing the effectiveness of the youth employment policy: focusing on the youth internship program for small and medium-sized enterprises and public institutions. Korean Soc. Public Admin. 29(2), 57-81 (2018)

Jung, E., Kang, S.: Effects of job loss on self-esteem: focusing on gender difference. Health Soc. Welfare Rev. 35(1), 84-109 (2015)

Kim, J.: The effects of labour market transition level on mental health of college graduates. Korea Educ. Rev. 24(1), 93-117 (2018)

Lee, S., Lee, Y.: Analytical results of panel survey on the career decision level and career preparation behavior of college students majoring in science and engineering. J. Eng. Educ. Res. 12(3), 73-78 (2009)

Lee, B., Kim, J., Ahn, J., Jung, J., Nam, G., Ryu, J., Jang, S., Choi, K.: A study on education and labour market. Korea Labour Institute, Seoul (2005)

Lee, G., Kang, D., Go, Y., Jeon, I.: The regional youth labour market's structure and how to create jobs. Korea Labour Institute, Seoul (2016)

Light, A.: In-school work experience and the returns to schooling. J. Labour Econ. 19(1), 65-93 (2001) 
Lynch, L.M.: The youth labour market in the eighties: determinants of reemployment probabilities for young men and women. Rev. Econ. Stat. 71(1), 37-45 (1989)

Machin, D., Cheung, Y.B., Parmar, M.: Survival analysis: a practical approach. John Wiley \& Sons, Hoboken (2006)

Mano-Negrin, R., Tzafrir, S.S.: Job search modes and turnover. Career Dev. Int. 9(5), 442-458 (2004)

Mau, W.C., Kopischke, A.: Search methods, job search, and job satisfaction of college graduates: a comparison of race and gender. J. Employ. Counsel. 38, 141-149 (2001)

Meyer, R.H., Wise, D.A.: The effects of the minimum wage on the employment and earnings of youth. J. Labour Econ. 1(1), 66-100 (1982)

Moon, Y.: Young Generation's Labour Market Gap and Secondary Outflow Determinants. J. Regional Labour Stud. 8(1), 73-105 (2018)

Nam, J.: Youth unemployment's dynamic characteristics and policy implications. Labour Rev. 16, 22-33 (2006)

OECD.: Employment Outlook. OECD, Paris (2017). Retrived Apr 2018 from https ://www.oecdilibrary.org/employment/oecd-employment-outlook-2017_ empl_outlook-2017-en

Park, G., Cheon, Y.: An analysis of factors affecting college graduates' employment. J. Employ. Occup. 3(1), 29-59 (2009)

Park, Y., Lee, H.: Differential wage effects of over-education among four distinct occupational classes and regional comparison. Korea Plan. Assoc. 49(3), 255-276 (2014)

Reid, G.L.: Job search and the effectiveness of job-finding methods. Ind. Labour Relations Rev. 25(4), 479-495 (1972)

Rosenberg, M.: Society and the adolescent self-image. 11. Princeton University Press, Princeton (1965)

Ruhm, C.J.: Is high school employment consumption or investment? J. Labour Econ. 15(4), 735-776 (1997)

Ryu, J.: A study on the first job of provincial college graduates. J. Employ. Skills Dev. 6(1), 1-25 (2003)
Salas-Velasco, M.: The transition from higher education to employment in Europe: the analysis of the time to obtain the first job. High. Educ. 54(3), 333-360 (2007)

Schmid, G.: Youth unemployment in Korea: from a German and transitional labour market. Point of View 63. IZA Policy Paper (2013). ftp.iza.org/pp63. pdf. Accessed 16 Feb 2017

Schwarz, N., Clore, G.L.: Feelings and phenomenal experiences. In: Higgins, E.T. Kruglanski, A. (eds.) Social psychology: a handbook of basic principles, 2nd edn, pp. 385-407. Guilford, New York (2007)

Statistics Korea: Employment Trend Press Release (2015). http://kosis.kr. Accessed 11 Feb 2018

Statistics Korea: Economically Active Population Press Release (2018). http:// kosis.kr. Accessed 11 Feb 2018

Steele, C.M., Spencer, S.J., Lynch, M.: Self-image resilience and dissonance: the role of affirmational resources. J. Pers. Soc. Psychol. 64(6), 885 (1993)

Van den Berg, G.J., Van Ours, J.C.: Duration dependence and heterogeneity in French youth unemployment durations. J. Popul. Econ. 12(2), 273-285 (1999)

Van der Klaauw, B., Van Vuuren, A., \& Berkhout, P. H.: Labour market prospects, search intensity and the transition from college to work (2004)

Vogel, P.: The youth unemployment crisis and the threat of a 'Generation Jobless". In: Vogel, P. (ed.) Generation jobless? Turning the youth unemployment crisis into opportunity, pp. 3-44. Palgrave Macmillan, Basingstoke (2015)

Wu, C.C.: High graduate unemployment rate and Taiwanese undergraduate education. Int. J. Educ. Dev. 31(3), 303-310 (2011)

Yoon, Y., Kim, Y., Oh, S., Kang, D., Kim, S.: Youth employment labour market's current status, problems and policy challenges. Korea Labour Institute, Seoul (2017)

\section{Submit your manuscript to a SpringerOpen ${ }^{\odot}$ journal and benefit from:}

- Convenient online submission

- Rigorous peer review

- Open access: articles freely available online

- High visibility within the field

- Retaining the copyright to your article

Submit your next manuscript at $\boldsymbol{\nabla}$ springeropen.com 